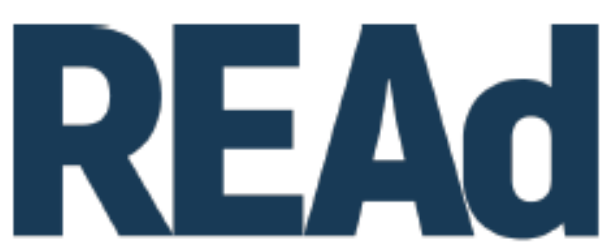

Revista Eletrônica de Administração

\title{
DESENVOLVIMENTO? PARA QUEM? RELAÇÕES ESTRATÉGICAS ENTRE EMPRESA E SOCIEDADE: O LADO OBSCURO DA PRIVATIZAÇÃO DA COMPANHIA SIDERÚRGICA NACIONAL (CSN) ${ }^{1}$
}

\author{
Anádia Oliveira da Silva ${ }^{2}$ \\ Márcio Moutinho Abdalla ${ }^{3}$ \\ http://dx.doi.org/10.1590/1413-2311.276.95590
}

\section{RESUMO}

Esta pesquisa teve como objetivo analisar as relações estratégicas desenvolvimentistas entre a Companhia Siderúrgica Nacional (CSN) e a sociedade de Volta Redonda/RJ no período de 1990 a 1993, época de privatização da empresa, com enfoque na redução dos movimentos populares, sociais e sindicais pós-privatização. Os dados foram coletados a partir de pesquisa documental e de entrevistas, e a investigação realizada mediante procedimentos teóricometodológicos da análise crítica do discurso de Norman Fairclough. Como principais contribuições, o trabalho demonstra a importância de se considerar os intervenientes de "nãomercado", além de evidenciar três ordens de discurso utilizadas estrategicamente para legitimar os interesses governamentais de cada fase. Os resultados da pesquisa apontam que o "desenvolvimento" não foi alcançado pelas parcelas menos favorecidas da sociedade, gerando maior assimetria social, desemprego, redução dos movimentos sociais e problemas ambientais, corroborando a necessidade de discussão a respeito da atual demanda pela minimização da interferência do Estado na economia.

Palavras-chave: Estratégia. Não-mercado. Neoliberalismo. Desenvolvimento. Política.

\section{DEVELOPMENT? FOR WHOM? STRATEGIC RELATIONS BETWEEN ENTERPRISE AND SOCIETY: THE DARK SIDE OF COMPANHIA SIDERÚRGICA}

\footnotetext{
${ }^{1}$ Recebido em 16/8/2019, aceito em 22/1/2020.

${ }^{2}$ Universidade Federal Fluminense - Programa de Pós-Graduação em Administração (PPGA); Volta Redonda RJ. (Brasil); https://orcid.org/0000-0001-7971-2120; anadiakta@hotmail.com

${ }^{3}$ Universidade Federal Fluminense - Programa de Pós-Graduação em Administração (PPGA); Volta Redonda RJ. (Brasil); https://orcid.org/0000-0002-2607-1021; marciomabdalla@gmail.com

(c) (1) $(2)$ REAd | Porto Alegre - Vol. 26 - N. ${ }^{\circ} 1$ - Janeiro / Abril 2020 - p. 49-80.
} 


\section{NACIONAL (CSN) PRIVATIZATION}

This research had as its purpose to analyse the developmentalists strategic relations between Companhia Siderúrgica Nacional (CSN) and Volta Redonda/RJ society from 1990 to 1993, when the enterprise was privatized, focusing on reducing post-privatization popular, social and union movements. Data were collected from documentary research and interviews, and the analysis performed using theoretical-procedures of Critical Discourse Analysis, by Norman Fairclough. As its main contributions, the paper demonstrates the importance of considering "non-market" actors, as well as highlighting three discourse orders strategically used to legitimize the governmental interests of each phase. The research results indicate that the "development" was not achieved by the less favored parts of society, generating greater social asymmetry, unemployment, reduction of social movements and environmental problems, corroborating the need for discussion about the current demand for the minimization of the interference of State in the economy.

Keywords: Strategy. Non-market. Neoliberalism. Development. Politics.

\section{¿DESARROLLO? ¿PARA QUIEN? RELACIONES ESTRATÉGICAS ENTRE EMPRESAS Y SOCIEDAD: EL LADO OSCURO DE LA PRIVATIZACION DE LA COMPAÑIA SIDERURGICA NACIONAL (CSN)}

Esta investigación tuvo como objetivo analizar las relaciones estratégicas de desarrollo entre la Compañía Siderúrgica Nacional (CSN) y la sociedad de Volta Redonda/RJ desde 1990 hasta 1993, período de privatización de la empresa, centrándose en la reducción de los movimientos populares, sociales y sindicales post-privatización. Los datos se recopilaron a partir de investigaciones documentales, entrevistas y el análisis que se llevó a cabo a través de los procedimientos teórico-metodológicos del análisis crítico del discurso de Norman Fairclough. Como principales contribuciones el documento demuestra la importancia de considerar a los actores "no-mercado", así como también destaca tres órdenes de discurso utilizadas estrategicamente para legitimar los intereses gubernamentales de cada fase. Los resultados de la investigación indican que el "desarrollo" no fue logrado por las partes menos favorecidas de la sociedad, generando una mayor asimetría social, desempleo, reducción de los movimientos sociales y problemas ambientales, lo que corrobora la necesidad de debatir sobre la demanda actual para minimizar la interferencia del Estado en la sociedad y en la 
economía.

Palabras clave: Estrategia. No-mercado. Neoliberalismo. Desarrollo. Política.

\section{INTRODUÇÃOO}

Desenvolvimento e modernização foram promessas difundidas mediante discurso de "necessidade" e única opção para a sociedade de Volta Redonda (RJ) desde 1941, ano de instalação da Companhia Siderurgica Nacional (doravante CSN) na cidade. O objetivo do governo Getúlio Vargas, presidente do Brasil à época, era constituir um "novo trabalhador" e uma "nova sociedade", a partir do discurso de libertação do campo, modernidade e desenvolvimento para o país. Em uma fase na qual o governo era considerado assistencialista e paternalista, a CSN era posicionada como uma "mãe" para os trabalhadores e para a cidade. Contudo a CSN também posicionava-se de modo autoritário, exercendo controle e domínio da economia, política e sociedade (PALMEIRA, 2012).

Diante dos processos de opressão, a Igreja Católica local, signatária da Teologia da Libertação, promoveu a catequização dos operários e líderes sindicais para a libertação do colonialismo interno empregado, fomentando greves, movimentações sociais e sindicais. A CSN ficou conhecida pela repercussão das grandes greves, como a de 1988, em que houve o assassinato de três operários (GANDRA, 2009).

O ano de 1990 trazia consigo novos fenômenos como o processo de consolidação do projeto de globalização neoliberal, mantendo ativas as promessas de desenvolvimento e modernização. Fernando Collor de Mello, defensor dos ideais neoliberais, assumiu a presidência da república em 1990 e, dentre as empresas que prometeu privatizar, estava a CSN, devido às grandes mobilizações e confrontos que ali existiam, além de ser considerada "gargalo" da economia e "espaço de corrupções" (SAWAYA, 2014; THEBALDI, 2015).

Como muitos posicionavam-se contra a privatização, o governo e a CSN elucubraram estratégias e práticas discursivas para legitimar a "necessidade" da política, e consequentemente, suprimiram o poder do sindicato e da população de Volta Redonda. A privatização concretizou-se em 1993, demonstrando a violência do projeto neoliberal e a quem ele verdadeiramente serve (BIONDI, 2014).

Após aprofundamento sobre o tema e observação pessoal, sobretudo por residirmos na cidade de Volta Redonda-RJ, identificamos que com o passar dos anos as movimentações por parte dos sindicatos, igreja e sociedade (atores de não-mercado) contra as ações da CSN 
foram significativamente reduzidas, e que tais reduções ocorreram especialmente após a privatização da CSN, o que motivou-nos a produzir o seguinte questionamento: as estratégias empregadas pela CSN em seu processo de privatização foram capazes de co-optar atores de não-mercado a ponto de minarem ações de resistência? A partir do questionamento, o objetivo deste trabalho é compreender as relações estratégicas entre a CSN e a sociedade de Volta Redonda/RJ no período de 1990 a 1993 (período de privatização).

Consideramos que o termo desenvolvimento possui diferentes significados: crescimento econômico, avanço social e desenvolvimento em seu aspecto mais amplo, o qual não diferencia crescimento econômico e desenvolvimento social. Destacamos que o termo “desenvolvimento" empregado neste trabalho é entendido tanto como crescimento econômico quanto social. Compreendemos que o processo de crescimento econômico não pode ser dissociado de desenvolvimento social, pois isso seria subdesenvolvimento disfarçado de desenvolvimento (ABDALLA; FARIA, 2019; FURTADO, 1961). A promessa de desenvolvimento frente a doutrina dos países hegêmonicos não passa de um subdesenvolvimento com diversas consequências negativas para o país em uma ilusória imagem de desenvolvimento ofuscado pela ideia de melhoria social, com externalidades negativas geopolíticas e sociais, expandido o projeto neoliberal e as assimetrias sociais (ABDALLA; FARIA, 2019; PEREIRA, 2006).

Destacamos, entretanto, que o subdesenvolvimento não é uma fase prédesenvolvimento, pois é característico de países subdesenvolvidos, frutos de políticas públicas disfarçadas de desenvolvimento e modernização não igualitárias, condicionadas aos projetos das grandes corporações, retrato da expansão capitalista desigual, que acarretam dependência e marginalização (CEPÊDA, 2012; PEREIRA, 2006; SUNKEL, 2000 ).

Para Celso Furtado (1961), desenvolvimento é bem mais que o atingimento de índices formais, é uma transformação global da sociedade, economicamente, institucionalmente e culturamente. Portanto, o processo de desenvolvimento deve ser compreendido não só pelo prisma econômico, mas também pelo social, político e histórico (ABDALLA; FARIA, 2019; CEPÊDA, 2004; CEPÊDA, 2012).

Especialmente no caso brasileiro, inicialmente tivemos um processo de desenvolvimento comandado pelo Estado, sendo depois entregue ao mercado a partir de ideais neoliberais. Assim como Celso Furtado (1961), defendemos a importância do Estado como força motriz do desenvolvimento.

O presente estudo mostra-se relevante para o campo, pois reflete o saber como prática, 
principalmente porque investigações empíricas em estratégias de não-mercado não são facilmente encontradas na literatura, sobretudo brasileira. Esta pesquisa contribui com o campo de conhecimento ao evidenciar relações discursivas de co-optação entre a CSN e os atores de não-mercado no período de sua privatização.

\section{FUNDAMENTAÇÃO TEÓRICA}

\subsection{CSN - DO PATERNALISMO AOS MOVIMENTOS SOCIAIS}

Após a crise de 1930 o cenário brasileiro evidenciava vontade de modificação do perfil do país, de agroexportador para urbano-industrial. Para que essa modificação e consequente desenvolvimento ocorressem, foram utilizadas várias estratégias, e uma delas foi a criação pelo Estado de empresas para fomentar a industrialização, além da criação de um novo perfil de trabalhador brasileiro (ALVES, 2001). Neste contexto foi criada a CSN, em 1942, em Santo Antônio de Volta Redonda, distrito de Barra Mansa, como promessa de desenvolvimento para o Brasil. Junto à sua criação, foi constituída uma cidade operária para abrigar os trabalhadores que migravam de diversos estados brasileiros. A cidade operária seguia os modelos da company town e, ao mesmo tempo que abrigava os "necessitados", também segregava e categorizava operários segundo sua posição hierárquica na empresa, conformando uma espécie de casta geográfica e social. Essa época foi marcada por um Estado típico keynesiano, Estado de bem estar social, com elevados gastos sociais e baseado no pleno emprego (ALVES, 2001; ASSIS; LUSTOZA, 2013; BENTES; COSTA, 2012; LIMA, 2014; PALMEIRA, 2012 ).

Em 1954, Santo Antônio de Volta Redonda emancipou-se de Barra Mansa, fazendo surgir a cidade de Volta Redonda, subordinada à indústria, a partir do fomento ao capitalismo moderno (PALMEIRA, 2012; PEREIRA, 2007). Entretanto, esse processo capitalista trazia problemas desde aquela época. Com a propagação da construção da siderúrgica CSN, houve grande migração de pessoas do campo para a cidade, iludidos pela promessa de uma vida melhor. Todavia, quando a construção da CSN encerrou, parte significativa da mão-de-obra empregada em sua construção não fora absorvida pela indústria, culminando em amplo desemprego. Esses trabalhadores não possuiam meios de retornarem ao campo, culminando na proliferação de favelas e na marginalização de excluídos. Os recém desempregados não desfrutavam das benesses da "família siderúrgica", passando portanto a viverem em situação 
sub-humana, sem qualquer infraestrutura (MOREL, 1989; PALMEIRA, 2012).

Ao retirar o trabalhador do campo com a promessa de uma vida melhor na nova era de desenvolvimento, o Estado não assumiu o papel de formador dos trabalhadores para que pudessem atuar posteriormente na indústria que construiam. Os "não-aptos" ao trabalho na indústria foram excluídos e marginalizados, revelando uma das piores faces deste modelo de "des-envolvimento", que privilegia grandes corporações e tudo mercadifica. Com o término da relação empregatícia, cessou-se também todo e qualquer envolvimento social com os trabalhadores e com a sociedade (HAESBAERT; PORTO-GONÇALVES, 2006; PORTOGONÇALVES; QUENTAL, 2012).

Nessa época, a CSN era tida como uma "mãe" para a cidade, pois fornecia as moradias, era proprietária dos hospitais, dos ambientes de lazer e das escolas. Boa parte de seus trabalhadores eram oriundos do campo, com baixa escolaridade, facilitando sua dominância e influência sobre a cidade. Por conseguinte, ocorriam poucas movimentações sociais anteriormente ao ano de 1984, quando houve a primeira greve. A repressão que existia dentro da siderúrgica e o controle da cidade-operária, além da ideia de "família siderúrgica" e CSN "mãe", alienavam a sociedade e ajudam a compreender o fato (GANDRA, 2009; MOREL, 1989; PALMEIRA, 2012).

O processo de alienção modificou-se com o passar dos anos, com a geração dos filhos dos operários que, em grande parte obtiveram mais instrução e formação que seus pais, e passaram a questionar o poder da indústria. Ao ingressarem na CSN, buscavam seus direitos como trabalhadores e sociedade, fomentando assim diversas greves e movimentações populares, com ampla agenda trabalhista e socal (BENTES; COSTA, 2012; GANDRA, 2009; PALMEIRA, 2012). Essas movimentações foram apoiadas pela Igreja Católica local, signatária da Teologia da Libertação, que formava, mediante discurso libertador, lideranças para o sindicato, movimentações populares e sociais, buscando dar voz aos marginalizados da cidade operária, e libertação trabalhadores, principalmente mediante as Comunidades Eclesiais de Base - CEB's (GRANDRA, 2009; MOREIRA, 2012).

Foram diversas greves desde 1984, mas a com maior repercussão ocorreu em 1988, com a invasão do exército, resultando na morte de três operários. Já a greve de 1990 foi considerada a maior greve de ocupação da CSN, porém também a maior derrota grevista, pois provocou a demissão de diversos operários sem conseguirem o que reivindicavam. Volta Redonda era conhecida pela magnitude de suas manifestações (GANDRA, 2009; PEREIRA, 2007). 
A relação de dependência e de subserviência à "mãe" da cidade ocultava o caráter de classe da exploração sofrida, afinal um dos propósitos era civilizar a população por meio da ideia de "família siderúrgica", estratégia política nacional, de criação de um novo perfil de trabalhador e de sociedade, cooptados e alienados, com impactos locais (BENTES; COSTA, 2012; GANDRA, 2009; LIMA, 2014; MOREL, 1989; PALMEIRA, 2012; PEREIRA, 2006, 2007). O estabelecimento da CSN em Volta Redonda foi um experimento de criação da "nova sociedade", disciplinada e hierarquizada, e do "novo trabalhador urbano" - dócil, civilizado, submisso e moldado de acordo com os interesses políticos e econômicos da época, refletindo uma cidade símbolo de "progresso" e "modernidade" (ALVES, 2001; ASSIS; LIMA, 2014; LUSTOZA, 2013).

\subsection{GLOBALIZAÇÃO E PRIVATIZAÇÃO}

A industrialização brasileira deu-se principalmente pelos altos investimentos governamentais, com a criação de diversas indústrias estatais. Mas, a década de 1990 trazia consigo uma nova ideologia desenvolvimentista de modernização. O Brasil vivia uma nova etapa política de troca de governo e desejava posicionar-se frente à economia global, numa nova fase de "desenvolvimento" e "modernização", imposta como "necessária" para o enquadramento brasileiro na economia mundial. Essas ações faziam com que o Estado deixasse de ser desenvolvimentista para ser liberal. A adesão ao projeto neoliberal era condição sine qua non para que o país se enquadrasse ao "novo perfil" de globalização, orientando-se às privatizações, à redução de políticas sociais e não intervenção estatal (BIONDI, 2014; NORONHA, 2009; SAWAYA, 2014).

A cartilha do Consenso de Washington era tida como modelo a ser seguido e os países que não aderissem aos seus ditames eram considerados atrasados e não desenvolvidos (CARRION; PINTO, 2014; VIZENTINI, 1997). O fenômeno da globalização envolvia não somente a abertura das fronteiras econômicas e a evolução dos meios de comunicação como a internet, mas principalmente uma nova fase do capitalismo, no qual quem regularia a economia global seria tão somente o (livre) mercado, gerando consequências econômicas, políticas, sociais e culturais (PINTO, 2014). O Estado passou de agente de desenvolvimento para agente regulador, sendo responsável somente pela promoção de justiça, segurança e poder de polícia (IBARRA, 2011; SAWAYA, 2014). O quadro concebido provocou (e continua provocando) grande desigualdade social e demandas por justiça socieconômica, as 
quais instituições como o FMI e o Banco Mundial não se preocuparam em minimizar (ABDALLA; FARIA, 2019).

O projeto de globalização neoliberal ganhou mais força no Brasil com a posse de Fernando Collor de Mello como presidente em 1990, dando início as diversas privatizações e a consequente minimização do Estado na economia, conforme prometido em sua campanha política. Dentre as empresas a serem privatizadas estava a CSN, cuja desestatização era considerada estratégica para seu governo, por ser a maior indústria siderúrgica da América Latina e por suas características de fortes movimentações sindicais e sociais (BIONDI, 2014; GRACIOLLI, 2007).

Contra essa "necessidade" de privatização da CSN ocorreram diversos movimentos, dentre os quais destacam-se a greve de 1990 e o movimento "abraço à CSN" - onde a população uniu-se ao redor da siderúrgica de mãos dadas em protesto contra o processo. Tais movimentações, em sua maioria, envolviam principalmente o sindicato, a igreja católica e a sociedade em geral, porém não tiveram grande repercussão e sucesso, pois a privatização "deveria" ocorrer a qualquer custo (GRACIOLLI, 2007; PALMEIRA, 2012). Para tanto, o governo federal iniciou forte campanha midiática em favor das privatizações, mediante estratégia discursiva de desmoralizar a CSN perante a sociedade, taxando-a como gargalo econômico e espaço de corrupções. Essas modificações fizeram o Brasil viver um momento turbulento, que se agravou com o processo de impeachment do então Presidente Fernando Collor, em 1992 (GRACIOLLI, 2007; PALMEIRA, 2012).

A privatização da CSN concretizou-se em 1993, com a posse do vice-presidente Itamar Franco, mediante diversas estratégias governamentais e empresariais. Volta Redonda, que era conhecida por grandes manifestações, com o aumento do desemprego, fruto do processo de privatização, silenciou-se. O quadro de medo fez com que as greves não mais ocorressem. O sindicato transformou-se num sindicato de "parceria" e a cidade se viu dependente da grande siderúrgica. Esses fatos ilustram o poder da grande empresa ao influenciar e moldar seu contexto sociocultural, pois independentemente de todas as manifestações e resistência, a privatização ocorreu e a cidade curvou-se ao poder corporativo (DA SILVA; ABDALLA; MORAES, 2015; DA SILVA; ABDALLA, 2016; GRACIOLLI, 2007; PALMEIRA, 2012 PEREIRA, 2007;). Por trás da privatização da CSN estava também o silenciamento das agendas sociais, conforme o interesse das elites brasileiras (DA SILVA; ABDALLA, 2016; GRACIOLLI, 2007). 


\subsection{RELAÇÕES ESTRATÉGICAS DE NÃO-MERCADO DESCOLONIZADAS}

A colonização do saber e do ser sempre estiveram presentes na sociedade brasileira sob suas várias formas de capitalismo. Foram e são utilizadas como meios de exercer poder, pressão, influência e expropriação colonial pelos países centrais, de acordo com os interesses econômicos externos, a partir do discurso de "modernidade" e "desenvolvimento", tanto na política desenvolvimentista quanto neoliberal (ABDALLA; FARIA, 2017; BALLESTRIN, 2014; DUSSEL, 2000; FORTE, 2014; HARVEY, 2011; LANDER, 2005; QUIJANO, 2005; SAWAYA, 2014).

Países hegemônicos autoentitulam-se portadores exclusivos da modernidade. Assim, nós, subalternos e subdesenvolvidos, fomos obrigados a aceitar a condição de "necessitados" de tal modernização, e o modelo destes como nosso, sob uma realidade que não nos pertence (ABDALLA, 2014; BALLESTRIN, 2014; IBARRA-COLADO, 2010; MIGNOLO, 2005 ), formando um sistema-mundo moderno com agendas supostamente globais (BALLESTRIN, 2014; FORTE, 2014). Além da colonialidade do poder, fomos submetidos também à colonialidade do saber, a partir de conhecimentos "universais" "made in EUA" e Europa que, por vezes, os importamos e os utilizamos sem consciência crítica (ABDALLA; FARIA, 2015; MIGNOLO, 2005; QUIJANO, 2005).

A área da gestão estratégica brasileira, seguindo essa vertente, também se submeteu ao "conhecimento" imposto pelos países centrais, restringindo-se, muita das vezes, a relação estrita de mercado, propagada pelas nações hegemônicas a partir do neoliberalismo, num claro processo de colonização do saber (ABDALLA, 2014; ABDALLA; FARIA, 2017; QUIJANO, 2005). É preciso romper essas barreiras mediante processos de descolonização do saber e da sociedade, compreendendo que as relações estratégicas ocorrem em ambiente institucional, em que empresas e governos agem transpondo os supostos limites do mercado (BARLEY, 2010; BARON, 1995; FLEMING; SPICER, 2014).

Assim sendo, ao investigar estratégia, deve-se levar em consideração todo o contexto espaço-temporal, e não considerar apenas aspectos do "mercado", a saber - clientes, concorrentes e fornecedores - mas também "além do mercado", a exemplo das entidades reguladoras, governos, cidadãos, mídia, ONG's, legisladores, grupos ativistas, grupos religiosos, associações de classe, associações de moradores, sindicatos, questões ambientais e demais atores sociais (de não-mercado). O mercado está rodeado pela esfera social, cultural e política, sendo assim, o que ocorre em seu entorno molda suas dinâmicas (ABDALLA, 2014; 
BACH; ALLEN, 2010; BARON, 1995; BARON, 2010; BARON; DIERMEIR, 2007; BARLEY, 2010; FARIA; ABDALLA, 2014a; HE, 2006;).

As empresas, a partir de suas vantagens institucionais e estratégicas, podem criar, captar ou aumentar suas vantagens estratégicas (BARON, 1995) e, por conseguinte, podem moldar seus respectivos ambientes institucionais (BARLEY, 2010). Governos se valem de estratégias para moldar seu ambiente, assim como as empresas moldam governos e sociedade para executarem o que desejam. Assim, o mercado não é tão livre conforme postulado (ABDALLA, 2014; BARLEY, 2010; FARIA; ABDALLA, 2014b). Sob essa ótica, consideramos as relações estratégicas entre a CSN e seus intervenientes de "não-mercado" (sindicatos, igreja católica, política e movimentos sociais).

\subsection{ESTRATÉGIA COMO CONSTRUÇÃO DISCURSIVA}

Discursos são compostos por interesses sociais, sejam eles de dominação, conscientização ou outras intenções. De acordo com a teoria social, o discurso constitui o interesse de seus enunciadores, que os produzem e os compartilham, objetivando poder e hegemonia dentro do campo que atuam. Portanto, discursos expressam a realidade social, declaram sistemas de crenças, ideologias e identidades sociais daqueles que os geram e do contexto em que são concebidos (FAIRCLOUGH, 2001; SILVA; GONÇALVES, 2017).

A decorrência dos discursos se dá através de relações políticas e ideológicas, que engendram ideologias em busca de hegemonia. Por conseguinte, a Análise Crítica do Discurso (ACD) pode nos ajudar a compreender essas relações de busca pelo poder e hegemonia, pois a ACD não afasta o discurso de seu contexto. Os sentidos são dados a partir do contexto social e não exatamente dos textos, sobretudo após a Virada Sociolinguística. Assim, a ACD visa revelar estruturas de poder, ideologias, crenças e instituições que estão compreendidas no discurso como fundamento de dominação e, por essas razões, trata-se de uma análise crítica (CHOULIARAKI; FAIRCLOUGH, 1999; FAIRCLOUGH, 1985).

Há conexões entre sociedade e linguagem em meio a um contexto ideológico na análise do discurso, gerando efeitos de sentido, que se podem compreender por meio de interpretação. A ACD não atua com o sentido do texto, mas com o sentido produzido e não traduzido (CAREGNATO; MUTTI, 2006; ROCHA; DEUSDARÁ 2005).

A ACD é dotada de capacidade de emancipação dos sujeitos, é uma nova maneira de ver o mundo a partir de um olhar crítico do discurso, imerso em seu contexto intitucional 
(social, histórico e cultural). Há relação do discurso com o que é constatado historicamente e com quem promove o discurso. Assim sendo, teoria e metodologia estão inter-relacionadas e não devem ser utilizadas isoladamente. Dessa forma, a ACD não deve restringir-se aos procedimentos metodológicos, sendo também rica e ampla abordagem teórica (FAIRCLOUGH, 2001; SILVA; GONÇALVES, 2017). Logo, a ACD, devido a sua natureza crítica e reflexiva, tem muito a contribuir para o campo da administração, a partir do estudo do discurso e seus contextos sociais, que desenvolvem a realidade e as práticas sociais e, ao mesmo tempo, são influenciados por elas (ABDALLA; ALTAF, 2018; SILVA; GONÇALVES, 2017).

Relações de poder, opressão social e dominação podem ser mantidas e construídas mediante estratégias discursivas, a partir das quais, práticas ideológicas e de poder são utilizadas para legitimar visões de mundo interessantes àqueles que enunciam o discurso (FAIRCLOUGH, 2001; SILVA; GONÇALVES, 2017). Práticas sociais abusivas evidenciam domínio de um determinado grupo (privilegiado) em detrimento de outro grupo (subalternizado), caracterizando abuso de poder. Tal dominação muitas das vezes é exercida mediante práticas discursivas estratégicas, que manipulam indivíduos a partir de seu consumo, de desinformação e de doutrinação, obscurecida por discursos produzidos e distribuídos por conselhos, regulações, leis, ordens e ameaças, que podem acarretar em transformações ideológicas, injustiças e desigualdades sociais (VAN DIJK, 2011). Tais consequências e impactos da utilização de estratégicas discursivas como ferramenta de exercer poder e manipulação dependerão das condições sociais e do grau de alienação e dominação dos sujeitos. Ainda que o sujeito não seja totalmente acrítico, passivo, ou "assujeitado" em todo processo estratégico discursivo, normalmente o discurso tende a influenciar seu modo de agir, pensar, relacionar, conceber e comportar o mundo da sociedade. Normalmente os sujeitos se adaptam ou constituem-se nessa ambivalência de ideologias e, por vezes, adaptam-se ao discurso hegemônico dotado de poder (FAIRCLOUGH, 2005).

\section{PROCEDIMENTOS METODOLÓGICOS}

O objeto da pesquisa nos direcionou para uma investigação de natureza qualitativa, pois era necessário entender a relação entre o mundo real e as instituições existentes, em busca da compreensão de uma realidade ainda não totalmente descrita (LAMY, 2011; MINAYO, 2009; SILVA; MENEZES, 2005; ). Quanto a sua finalidade, a pesquisa pode ser 
considerada explicativa, pois busca entender as causas do fenômeno pesquisado, e descritiva, visto que se destina à descrição dos fenômenos ocorridos no período de recorte do estudo (GIL, 2002; SILVA; MENEZES, 2005). Dado o caráter histórico e atual que envolve a investigação, visando desvendar possíveis motivos para a redução das movimentações populares e sindicais com o passar dos anos, os dados foram coletados a partir de pesquisa documental e de entrevistas em profundidade com atores importantes para o campo da pesquisa, sem ater-nos aos metadiscursos hegemônicos postulados.

A pesquisa documental deu-se principalmente a partir de documentos fornecidos pelo arquivo da CSN, pela Cúria Diocesana, e por dois entrevistados ${ }^{4}$. Além disso, obtivemos acesso a duas correspondências enviadas pelo presidente da CSN em 1993 à Comissão de Desestatização. No arquivo da siderúrgica encontramos documentação de 18 de setembro de 1992, denominada "Mural", que compreendia mais de 100 perguntas e respostas aos funcionários, elaborada pelo presidente da CSN, em discurso sobre a privatização. Em Graciolli (2007), localizamos cartas enviadas pela siderúrgica aos familiares dos operários a respeito da privatização, que também compuseram nossa análise documental.

Já as entrevistas foram realizadas com 10 atores, representando a classe política, operária, sindical, igreja e movimentos sociais, conforme as figuras 01 e 02 . Vale mencionar que foram entrevistados dois dos presidentes da CSN durante o período de pré-privatização e durante a privatização; quatro operários que trabalhavam na CSN durante tal processo, sendo que um deles trabalha atualmente na siderúrgica; um (ex) prefeito de Volta Redonda e um (ex) Deputado Federal do período da privatização, sendo que o aludido deputado também participava da Comissão de Desestatização; um funcionário da Cúria Diocesana, "braço direito" do Bispo da época, contrário à privatização, que também atuava em movimentos sociais; o líder do movimento Ética na Política, que surgiu na Igreja Católica, assim como o coordenador da Pastoral Operária da Igreja Católica. Totalizando cerca de 15 horas de entrevista.

\footnotetext{
${ }^{4}$ ("Discurso de Transmissão do Cargo de Presidente da Companhia Siderúrgica Nacional, em 23/04/1993” e carta enviada pelo operário entrevistado aos seus companheiros de trabalho após sua demissão.
} 
Figura 1: Macro ambiente considerado

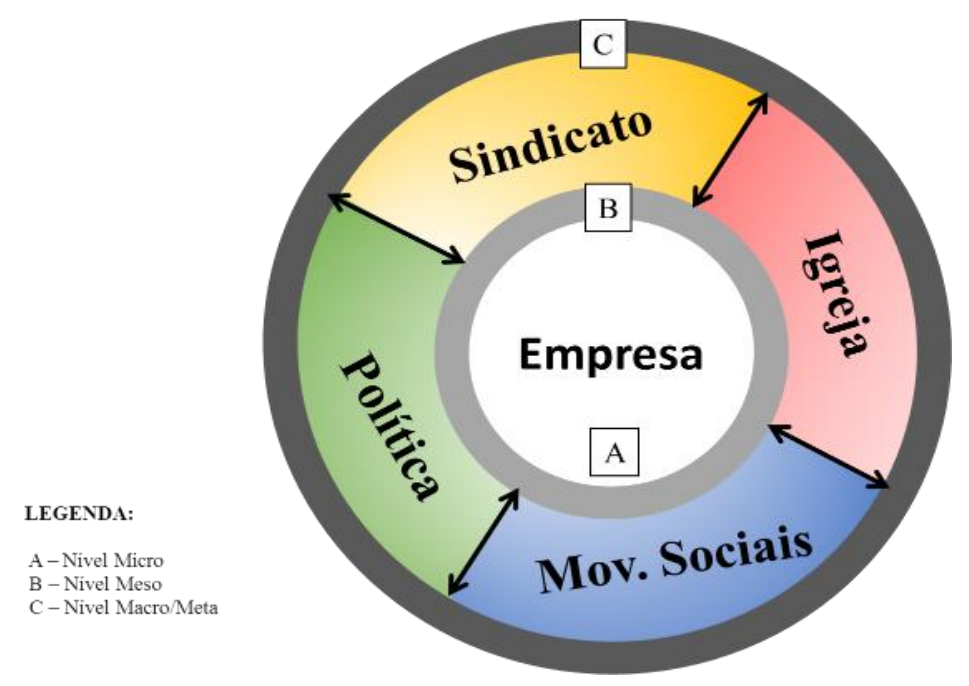

Figura 2: Escolha dos atores

\begin{tabular}{l|l|l|l|}
\hline Ator & Posição & Entrevistado & Duração \\
\hline Empresa & Presidente & Entrevistado 01 & $1: 40: 49$ \\
\hline Empresa & Presidente & Entrevistado 02 & $1: 02: 35$ \\
\hline $\begin{array}{l}\text { Empresa } \\
\text { Empresa / Igreja }\end{array}$ & $\begin{array}{l}\text { Funcionário 01 } \\
\text { Operário 01 / Funcionário e braço direito do } \\
\text { Bispo a época (Dom Waldyr Calheiros) }\end{array}$ & Entrevistado 03 & $1: 59: 11$ \\
\hline $\begin{array}{l}\text { Empresa / Igreja } \\
\text { Empresa/ Movimento } \\
\text { Social / Igreja }\end{array}$ & Operário 02 / Coordenador & Eperário 03 / Coordenador & $2: 38: 50$ \\
\hline $\begin{array}{l}\text { Política } \\
\text { Política }\end{array}$ & Prefeito & Entrevistado 06 & $1: 13: 29$ \\
\hline Sindicato & Deputado Federal & Entrevistado 07 & $1: 13: 29$ \\
\hline Sindicato & Presidente & Entrevistado 08 & $1: 32: 20$ \\
\hline & Presidente / Operário 04 & Entrevistado 09 & $2: 04: 13$ \\
\hline
\end{tabular}

A análise dos dados baseou-se nos procedimentos teórico-metodológicos da ACD de Norman Fairclough, a partir de seu modelo tridimensional, com ênfase na prática social, pois acreditamos que a realidade social revela-se no discurso, expressa ideologias, crenças, poder e interesses de seus enunciadores (FAIRCLOUGH, 2001; SILVA; GONÇALVES, 2017). As análises também foram suportadas pelo framework metodológico sistematizado por Abdalla e Altaf (2018). Ademais, a ACD possibilita considerar o contexto social, cultural e histórico do fenômeno investigado e como ela constrói tal contexto e o modifica, mediante análise tridimensional (textual, discursiva e social) (ABDALLA; ALTAF, 2018; FAIRCLOUGH, 2001; SILVA; GONÇALVES, 2017;). 
Assim, conforme o framework sistematizado por Abdalla e Altaf (2018), nossa análise dos dados inicou-se com a definição das unidades de análise. Analisamos o contexto e a problematização, conforme explicitado na problemática da pesquisa, a partir de referenciais teóricos, pesquisa documental e análise pessoal, que nos ajudaram a definir o objetivo da pesquisa e o corpus a ser tratado. Essas análises iniciais foram muito importantes, pois nos deram subsídios suficientes para prosseguir para a próxima etapa, com pressupostos mais consistentes a serem analisados, pessoas a serem entrevistadas, documentos a serem buscados e quais atores de não-mercado seriam foco do estudo.

Já de posse de todos os dados coletados, demos início a análise prelimar dos dados, organizando-os em categorias definidas a priori (segunda etapa do framework). Nossa escolha inicial consistiu em separar os dados na categoria de não-mercado que cada ator pertencia. Por exemplo, quando entrevistamos o ex-presidente da CSN, organizamos a transcrição de sua entrevista na seção "Empresa", já quando conversamos com o prefeito de Volta Redonda à época, enquadramos na seção "Política" e assim por diante. Destacamos que no momento da transcrição, realizamos uma segunda análise preliminar dos dados, destacando tudo aquilo que nos despertava a atenção.

Após concluir a análise preliminar, observamos que as categorias analíticas definidas a priori não atendiam satisfatoriamente ao objetivo da pesquisa, pois os resultados da análise preliminar trouxeram informações inéditas e de maior relevância para o estudo, oportunizando melhores contribuições ao trabalho (GRAEBNER, MARTIN \& ROUNDY, 2012). Assim, reorganizamos as categorias analíticas de acordo com as três ordens do discurso que sobressaíram nas entrevistas e nos documentos (terceira etapa do framework), e que foram confirmadas após análise textual, das práticas discursivas e das práticas sociais, ou seja, coforme proposto por Abdalla e Altaf (2018), ocorreu o desvelar de categorias emergentes (CSN “mãe”, CSN "gargalo", CSN privatizada), que foram importantes para as análises finais, os resultados e as contribuições deste trabalho.

\section{PRINCIPAIS ACHADOS}

Dentre os principais achados do trabalho, puderam-se observar três ordens do discurso ressaltadas pelos entrevistados, ao se referirem a cada uma das fases de atuação da CSN na cidade de Volta Redonda, até sua privatização. Inicialmente foi tida como CSN "mãe", como provedora da cidade, posteriormente como CSN "gargalo" da economia, quando desejavam 
legitimar sua privatização e, por último, como CSN privatizada, "opressora”, representando a atual relação da empresa com a sociedade local.

\subsection{CSN "MÃE"}

Dentre as diversas ações realizadas por Getúlio Vargas para fomentar o processo de industrialização brasileira, ressaltamos a construção da CSN em Volta Redonda. Entretanto, a construção da siderúrgica conjuntamente com uma cidade operária objetivava muito mais que a industrialização, objetiva também a construção de uma nova sociedade e um novo perfil de trabalhador brasileiro, conforme elucidado pelo líder sindical, entrevistado 09: “(...) o projeto inicial da CSN era alavancar o desenvolvimento da indústria no Brasil, traçar um modelo de operário (...)”.

O entrevistado 9 utilizara a palavra "modelo" para descrever o perfil de operário que o governo da época desejava construir. $\mathrm{Na}$ análise textual podemos não somente destacar o uso do vocabulário "modelo", mas também da palavra "operário". Sob uma contextualização histórica, ambos os vocábulos refletem o perfil de trabalhador almejado: uma pessoa que realizaria o trabalho manual e braçal, em troca de um salário, sem muitos questionamentos, ou seja, alienado. Portanto, essas pessoas que iniciavam o processo industrial brasileiro deveriam ser monitoradas e controladas, para que a experiência de industrialização fosse favorável ao governo e aos grandes empresários.

A retirada do trabalhador do campo e as promessas de uma vida melhor dava à Vargas o título de "pai dos pobres", suportado pela ideologia paternalista que constituiu a grande siderúrgica como "mãe" para a cidade de Volta Redonda, especialmente para aqueles que viviam na cidade operária, onde havia relação de subserviência e dependência mediante a ideia de "família siderúrgica". Esse significado também pode ser identificado na fala do entrevistado 09: “(...) Getúlio Vargas, o pai, quem tirou o trabalhador das mãos do fazendeiro (...)". O papel opressor e explorador da empresa era camuflado pela narrativa de que a vida no campo era penosa e a empresa salvaria o trabalhador da difícil vida, imposta pelos fazendeiros.

No decorrer das várias entrevistas, os discursos que remetiam ao afeto familiar relacionavam-se aos sentimentos dos empregados para com a empresa, e do governo para com a sociedade. Posto isso, há de se refletir sobre a idealização de um presidente como "pai dos pobres" e uma empresa como "mãe". Tanto o vocabulário "pai" quanto "mãe" relacionam-se 
com proteção, cuidado, zelo, mas também lexicalizam a face de domínio, controle, portanto, uma narrativa autoritária e contraditória. Em outras palavras, aquele e aquela que ao mesmo tempo cuida, também controla, vigia e pune. Ademais, esse era o discurso vendido à época como símbolo de progresso brasileiro, tendo o campo como algo ruim para o brasileiro. Construía-se discursivamente a imagem do sonho de trabalhar "na cidade", por meio dos processos de industrialização. A prática discursiva produzida e distribuída pelo entrevistado 9 reflete essa lógica, ao dizer que Getúlio "tirou o trabalhador das mãos do fazendeiro".

O discurso produzido de CSN "mãe" foi distribuído e consumido em larga escala pela população de Volta Redonda, fomentando sua apropriação e interdiscursividade a partir de seu amplo emprego pelos entrevistados, sobretudo ao designarem o papel da CSN para com a cidade e para com a população anteriormente à privatização. Similarmente, refletindo a relação afetiva entre CSN e sociedade, Vargas era tido como "pai”. Assim a siderúrgica e Vargas eram tidos como supostos salvadores de Volta Redonda. A relação de dependência, poder, hierarquização espacial da cidade e controle, eram ocultos pelo assistencialismo, que era dado à população a partir de práticas sociais. Era a CSN que fornecia moradias, hospitais, clubes para lazer, polícia e escolas.

A cidade chegou a ser considerada área de segurança nacional em função da CSN. O poderio da empresa era expresso até mesmo em sua influência nas eleições para prefeito da cidade, refletindo nas ações da administração municipal, o que também era confundido como benfeitoria da siderúrgica para com a cidade, conforme discurso do entrevistado 08: “(...) CSN ajudava muito o Município, na administração do Município (...)”. Ou seja, a ideia de CSN "mãe" é caracterizada por uma clara inversão de valores, na qual a empresa que governava a cidade e à qual o governo deveria se submeter.

O uso do vocabulário "mãe" era empregado com muito orgulho, ocultando a marginalização e a exclusão daqueles que não habitavam na cidade operária e, portanto, não pertenciam à família siderúrgica. Ademais, a ditadura militar vivenciada à época influenciou sobremaneira essa relação de repressão e opressão daqueles que ali trabalhavam, mas não aceitavam a domesticação. Segundo o líder sindical, que fez parte da "família siderúrgica" (entrevistado 09), aqueles que não seguiam os ditames da empresa eram reprimidos e demitidos, pois havia um controle realizado "a pente fino".

Com o passar dos anos, e com uma nova visão daqueles que entravam na siderúrgica, muitas das vezes filhos dos próprios operários, com escolaridade mais elevada que a dos pais, a ideia de CSN "mãe" foi desgastando-se e a exploração e poder da siderúrgica foram sendo 
desvendados. Iniciaram assim as movimentações sindicais e sociais, incentivadas principalmente pela Igreja Católica, sob a égide da Teologia da Libertação, conforme relatou o entrevistado 04: “(...) tivemos apoio de toda igreja, dos movimentos sociais, vários sindicatos de todo o país vieram nos apoiar na greve de 88 (...)”, demonstrando a união dos diversos movimentos que existiam durante a greve de maior repercussão que ocorrera na CSN, em função da morte de três operários pelo exército. O entrevistado também refere-se ao agir da siderúrgica frente às movimentações como aquela que "vigiava", para demitir aqueles que participavam das greves e movimentações, e a "matava", em alusão à greve de 1988.

O desenvolvimento e a modernidade prometidos pelo Presidente Vargas retirou diversos trabalhadores do campo e, com isso, produzia-se um discurso que exaltava Volta Redonda como símbolo de "progresso" e "modernidade". Entretanto, a "modernidade" gerou exclusão, separação de classes, pobreza, dominação, colonização e controle, sobretudo ao considerarmos a grande massa populacional que perdeu seus postos de trabalho e manteve-se marginalizada na cidade, não retornando aos seus domicílios de origem no pós construção da siderúrgica.

\subsection{CSN "GARGALO”}

Objetivando seguir os ditames neoliberais, desenvolver-se e adequar-se à cultura global, a CSN foi utilizada pelo governo federal para demonstrar a adesão ao processo de saída do Estado da economia, sob uma lógica capitalista global de liberalização de mercado. No entanto, para que o Brasil fosse considerado "moderno" e "desenvolvido", o processo de privatização das empresas estatais, dentre elas a CSN, deveria acontecer rapidamente, sem diálogos e grandes movimentações. Portanto, era necessária uma estratégia que permitisse que isso ocorresse com o apoio de todos, principalmente daqueles que compunham o ambiente de não-mercado, a exemplo da igreja, dos sindicatos, do meio político e da sociedade. Destarte, foram utilizadas tanto estratégias de soft power quanto de hard power para legitimar a ideia de privatização da siderúrgica (NYE, 2005), materializadas principalmente pelo discurso de CSN "gargalo" econômico.

Essa rapidez do processo de privatização foi destacada por alguns dos entrevistados, principalmente quando referiam-se às tentativas de diálogos contra essa ação. O entrevistado 07, por exemplo, refere-se ao processo como algo imposto de cima para baixo, ressaltando que não houve debate. Fala apoiada pelo entrevistado 08, ao destacar que não concordou com 
o valor de venda da siderúrgica e como o processo foi concebido, segundo ele “(...) determinação superior (...). ” De acordo com o entrevistado 04, que reitera a lógica pretendida à época, a “(...) empresa ia dar muito emprego, ia se modernizar, porque o mundo inteiro estava fazendo isso, e que era preciso (...)”. A interdiscursividade representada nas falas reflete a lógica globalizante, descrita como "necessária", a partir da imposição do modelo hegemônico oriundo dos países centrais, por meio das práticas discursivas. Também é relevante ressaltar, sob a perspetiva da análise textual, o uso do vocabulário "modernizar", coeso à estrutura de justificativa, baseada na ideia de que se "o mundo inteiro estava fazendo isso", por que nós não estávamos fazendo ainda? A coesão textual é finalizada com a declaração de que aquilo "era preciso", conectando às práticas sociais hegemônicas e ideológicas, sob o ponto de vista da imposição de agendas oriundas de países centrais, a exemplo do próprio Consenso de Washington (PEDROSO NETO, 2002). Impunha-se uma espécie de pacto de modernidade sob a construção discursiva de adaptar-se ou perecer. Sob essa lógica, a modernização era simplesmente uma prática discursiva estratégica para captar a aceitação dos novos acionistas operários, o que contribuía não só como a divulgação e aceitação do processo de privatização, mas também para a legitimidade do mesmo.

Os países que não se adequassem ao modelo estariam privados da modernização, considerados atrasados frente às mudanças globais. A partir do pensamento colonial, nações hegemônicas "civilizavam" e "doutrinavam" países ditos subdesenvolvidos, mediante os discursos de que o mundo inteiro estava privatizando e que o Brasil precisava privatizar para desenvolver-se. Essas ideias refletem-se no discurso do líder sindical, entrevistado 10:

(...) isso teve forte influência direta no comportamento de movimento social aqui, uma derrota, e não uma derrota localizada não, uma derrota mundial, com a tal da globalização e se vendeu a ideia de que: "olha o mundo agora é um grande circo que nós temos que participar disso, porque acabou essa história de Estado de bemestar-social” (...) (Entrevistado 10).

Para que o processo de privatização acontecesse rapidamente e sem grandes "problemas", o governo federal junto à CSN realizou ações estratégicas com lideranças políticas, sindicais e sociais do seu ambiente de não-mercado, principalmente mediante discurso de cooptação, destinado a legitimar a privatização. Com ajuda de grande campanha midiática, a privatização da CSN era tida como imprescindível para a sua modernização e sobrevivência frente à competitividade. Adicionalmente, a CSN era recorrentemente desvalorizada pelo governo federal, sob discurso de que era corrupta e representava gargalo econômico, um "elefante branco" que iria inevitavelmente falir. 
Mas além do uso da mídia, a CSN utilizou de interlocução direta com a sociedade, enviando cartas às esposas dos funcionários em busca de apoio ao projeto de privatização. Essas cartas, que compuseram os documentos analisados nesta pesquisa, são exemplos táticos de utilização discursiva de soft power, pois a partir delas a CSN aproveitava-se do sentimento de cuidado com a cidade (retomando a ordem do discurso de "CSN mãe"), recorrendo a valores familiares, religiosos, sociais e de comunidade. Em suas palavras, "(...) a privatização fará de Volta Redonda, uma cidade feliz" (GRACIOLLI, 2007). Inclusive havia a promessa de que não haveria demissão em massa e que a privatização geraria mais emprego, o que não ocorreu de fato. Outra estratégia soft power utilizada pela empresa foi a venda de ações para seus operários, juntamente com a ilusão de riqueza a partir do processo de desestatização. A estratégia é corroborada na fala dos entrevistados 04 e 10, respectivamente: "O governo precisava que os trabalhadores estivessem no processo (...)” e “(...) foi entregue. Fica para você, e a gente (governo) vai vender o sonho (...)".

Ao associar os operários ao processo de privatização, a siderúrgica buscava que eles defendessem o processo, ou seja, estratégia de cooptação da sociedade e dos operários. O entrevistado 04 demonstra o outro lado desse processo: "Eles exploravam aquilo que todo mundo tem dentro de si, de perverso, o egoísmo, o querer ter. Eles começaram a explorar isso: vocês vão ficar ricos (...)”. Endossando esse discurso, o ex-operário, entrevistado 06 menciona que "falavam que íamos ficar ricos. Eu não comprei as ações, penso que ou você é contra ou a favor. (...)podem até ter conseguido comprar um carro, uma casa, mas ninguém ficou rico". Observamos nos discursos que a relação de realização de "sonhos", "riqueza" foram amplamente divulgadas juntamente com o discurso de "modernização", felicidade e desenvolvimento. Tais discursos eram distribuídos em larga escala a cada ator social, de acordo com sua vulnerabilidade.

Outro ator de não-mercado cooptado pelo processo de privatização foi o sindicato, mediante propagação da venda de ações por alguns dos diretores do sindicato, conforme dito pelo entrevistado 04: “(...) o sindicato caiu novamente na mão da empresa, isso foi muito ruim para o movimento sindical de Volta Redonda (...) Houve um retrocesso muito grande (...) contribuiu para a privatização (...)”.

A relação da CSN com os diversos atores de não-mercado, demonstra que a mesma compreendia a importância destes para o sucesso de suas estratégias, a importância das relações para além do mercado. Portanto, a empresa também buscou influenciar o meio político da cidade, pois sabia que políticos cooptados facilitariam a privatização da siderúrgica e demais 
ações da mesma, à custa de diversos prejuízos para a cidade, principalmente com o enxugamento do número de empregos. A respeito disso, o entrevistado 06 explica que a CSN chegou até mesmo a apoiar candidatos a prefeito da cidade na época da privatização. Todo o processo era como um enorme teatro de fantoches, amplamente manipulado pela "(ex) mãe" CSN.

(...) Tinham reuniões constantes sobre a privatização, para convencer os operários. A CSN chegou até a investir na candidatura de um prefeito, pois um prefeito a favor da privatização e da indústria seria benéfico, mas não ganhou as eleições. Eles desejavam que os operários vestissem a camisa da empresa e a camisa deste candidato (...) (Entrevistado 6).

Ademais o discurso para legitimar a privatização associado à pressa para realizar o processo ocasionou diversos problemas como a venda de terrenos da empresa juntamente com a siderúrgica, assim como o preço de venda aquém do valor de mercado. Quase todos os entrevistados citaram a venda dos terrenos, principalmente porque a venda limitou o crescimento econômico e estrutural da cidade, algo que era constantemente prometido durante o processo de privatização, e infelizmente não ocorreu.

O problema deu-se principalmente pela rapidez do processo de privatização, conforme relatado pelo entrevistado 01: “(...) tenho que desculpar o BNDES, porque a pressão era muito grande (...)”, ao referir-se ao processo de venda dos terrenos junto com a siderúrgica, ou seja, a culpa, segundo o mesmo era da rapidez do processo. Diferentemente, o entrevistado 02 destaca que havia conhecimento de que as terras compunham o edital de venda da siderúrgica, citando inclusive que pediu revisão do preço de venda e que o ativo não operacional (terras e imóveis) não fossem inclusos: “(...) o objetivo era facilitar a venda para as empresas que foram beneficiadas na aquisição. Só vejo isso como interesse financeiro (...)”. A informação é corroborada pelo entrevistado 10, que destacou a existência de pessoas que sabiam da inclusão das terras no edital e buscavam esconder o fato.

As estratégias utilizadas pela siderúrgica e pelo governo federal fizeram com que a CSN fosse rapidamente ressignificada de "mãe" a "gargalo" e problema social, beneficiando aqueles que a adquiriram e as camadas mais abastadas da sociedade. A CSN foi instrumento político, econômico e governamental para reduzir o poder de articulação da população contra a empresa e contra o governo, mediante cooptação do sindicato e movimentos sociais, num claro mecanismo de colonialismo interno e opressão.

O sentimento anterior de orgulho e pertencimento passou a revolta, em virtude da privatização, principalmente pela culpa da demissão, que recaiu sobre trabalhadores, tidos 
como aqueles que se não se adaptaram ao novo modelo de empresa ou aquele que não era um "bom" trabalhador. A fala do entrevistado 04 revela esse sentimento: "Eu ía me esquecendo de dizer que, durante esses 20 anos, não faltei nenhum dia de trabalho, não tive nenhuma advertência, não tive dispensa médica.". Muito mais que destacar as palavras transcritas neste relato, devemos refletir sobre os processos hegemônicos e o consequente ressentimento do trabalhador, que transcedeu ao discurso do entrevistado, chegando a chorar durante a entrevista, e ao saudosismo do mesmo ao falar de sua relação inicial com a empresa e de suas expectativas durante a construção da mesma. A estrutura textual concebe um encadeamento de argumentos que revelam a frustração do trabalhador frente sua incansável dedicação ao trabalho, sendo, no entanto, completamente desconsiderada no processo de demissões. $\mathrm{O}$ exemplo desnaturaliza a máxima dos benefícios da privatização e demonstra que a privatização da CSN gerou muito mais que problemas econômicos, financeiros, mas também psicológicos com a venda de uma empresa simbolo nacional.

Tão forte foi o discurso de "necessidade" de privatização e de CSN "gargalo" que, apesar das movimentações que ocorreram contra esse processo, a siderúrgica foi privatizada. A narrativa de "mãe" passou a ser utilizada para referenciar uma despedida do vínculo com a siderúrgica, num processo de transição e (des)conscientização: “(...) uma mãe não faz isso com seu filho, um pai não faz, morre, mas vai até o final, ele não fica falando: pega meu filho, e deixa levar (...)” (Entrevistado 9). A transição entre as ordens do discurso é claramente revelada por meio da ressignificação do nome CSN, passando de "Mãe" a "Gargalo" e, na sequência, uma CSN “privatizada” e opressora.

\subsection{CSN PRIVATIZADA}

A privatização da CSN concretizou-se em 1993, demonstrando o poder do mercado e a adesão ao projeto global de liberalização econômica, imposto como necessário, a partir de um discurso de empresa gargalo. A partir de então, o Estado passou de agente de desenvolvimento a Estado regulador, mediante processo que culminou em vários impactos para os movimentos sociais e sindical, assim como para a cidade de Volta Redonda, trazendo consequências destacadas também pelo entrevistado 10:

(...) há um custo social enorme, famílias que foram desagregadas, pessoas que perderam o emprego, pessoas que sofreram com isso, não só aqui na região (...) (...) aí você diz assim: mas isso foi um sucesso depois, porque a empresa está em pé (...) (...) a questão é que (...) deu certo? Deu, a um custo grande, a uma vida de escravo (...). O que se fez foi diminuir o valor da mão-de-obra (...). (Entrevistado 10). 
Até mesmo as instituições que tiveram papel central de combatividade mudaram seu perfil e relacionamento com a empresa e meio social. $\mathrm{O}$ ambiente de não-mercado foi modificado pelas estratégias de cooptação empregadas para legitimar a privatização. De acordo com os entrevistados, a atual relação com as instituições sindicais é de um sindicato cooptado a favor da empresa, "acoitado" que, pelo novo caráter de empresa privada, vê-se impossibilitado de desenvolver negociações profícuas, o que influencia também no modo de agir da sociedade, que tinha apoio do sindicato combativo e seguia suas ideologias, conforme expressou o entrevistado 10 .

(...) como a privatização foi feita com a concordância do sindicato e com a derrota do movimento social que a cidade tinha até então, porque o movimento foi derrotado, quando a gente perde a eleição sindical (...) (...) a CUT perde o sindicato, a igreja que tinha também um papel fundamental social na cidade, também perde essa força e o governo diz 'vou privatizar', e 'vou privatizar mesmo' $e$ iniciou uma série de demissões. Com as demissões, com o desespero nas famílias, então ninguém consegue se organizar e sem nenhuma outra perspectiva (...) (Entrevistado 10).

A relação da Igreja Católica com a CSN também se modificou. O segmento teológico de libertação perdeu forças e aqueles que formam a igreja também perderam a visão de que deveriam lutar por seus direitos, que não deveriam mais questionar, sobretudo, pelo medo da demissão. A base da igreja continua a mesma, preocupando-se com oprimidos e menos favorecidos, mas a relação atual é diferente: “(...) a relação atual entre CSN e igreja é de distanciamento de interesses, mas a igreja busca a justiça (...) (...) a CSN é muito fria, não está escutando ninguém (...)" (Entrevistado 4). O relacionamento de distanciamento que a empresa mantém na atualidade com as instituições e com a sociedade facilitou a destituição da ideia de "família siderúrgica", constituindo uma sociedade sem consciência crítica e de classe, cooptada pela empresa. O Entrevistado 5 destaca que a ideia de "líder" e "operário de confiança", denominações dadas àqueles que se destacavam a favor dos interesses da empresa com poder de influenciação dos demais, contribuíram para desmobilizar as movimentações que ocorriam a época.

Já a relação da empresa com o governo do munícipio continuou de dependência. A cidade depende da siderúrgica mesmo após a privatização. O quadro é agravado pela impossibilidade de crescimento estrutural e econômico do município, motivado pela venda de $36 \%$ da área urbana da cidade juntamente com a siderúrgica (BENTES; COSTA, 2012; LIMA, 2012; PALMEIRA, 2012). O crescimento estrutural e econômico de Volta Redonda 
esbarra direta e/ou indiretamente no poder da grande empresa (LIMA, 2014). A estratégia que pode ser considerada um monopólio locacional de bancos de terras, limita o crescimento estrutural e econômico da cidade, em um processo de gentrificação que afeta os menos favorecidos, sob consequências planejadas e forçadas por um modelo imposto de privatização (ANDERSSON; TURNER, 2014; COWLING; TOMLINSON, 2005; ZHENG; KAHN, 2013;). Para desvincular-se do poder da siderúrgica, as políticas públicas de Volta Redonda a direcionaram a investir em um polo de serviços, mudando a lógica industrial. No entanto, no que tange ao crescimento estrutural e econômico, o poder da CSN é dominante.

Ao questionar os entrevistados sobre o emudecimento de agendas, sobre os motivos da redução das movimentações sociais e como é a relação atual da empresa para com a sociedade, os mesmos, quase que de forma uníssona, responderam que reside no poder que a CSN mantém sobre a cidade, além da própria conjuntura nacional e internacional. Os funcionários temem pela demissão, além de estarem dominados e colonizados pelo sistema que os envolve, a ponto de colocarem os ideais de mercado à frente dos interesses da sociedade, como a preservação do meio ambiente e da sociedade.

Mediante ideia de libertação, era difundido o discurso de CSN "mãe”, já quando da necessidade de privatização a CSN era tratada como problema social, "gargalo" econômico, que deveria ser contido a partir da mercadificação de agendas sociais, direitos e estratégias neodesenvolvimentista e neocoloniais. Atualmente, o poder e o discurso da grande siderúrgica ofuscam agendas sociais. A privatização está legitimada, e a carência de voz e repercussão dos movimentos que resistiram advém da opressão e do poder da grande siderúrgica. Assim finaliza o entrevistado 10: "(...) a privatização deu certo pra quem? Deu certo para os empresários, para quem participou do bolo (...)”.

\section{CONSIDERAÇÕES FINAIS}

O propósito deste trabalho residiu na compreensão das relações estratégicas entre a CSN e a sociedade de Volta Redonda/RJ no período de sua privatização. A principal motivação que impulsionou a investigação foi o questionamento sobre o poder e a consequente capacidade da agenda neoliberal em co-optar atores de não-mercado a ponto de minarem ações de resistência e, por conseguinte, silenciar as agendas sociais.

Dentre as contribuições propiciadas pela investigação, destacamos especialmente duas, sendo a primeira delas de ordem acadêmica, sobretudo por evidenciar, por meio de estratégias 
discursivas, e por bagagens decoloniais e históricas, as ações empreendidas pela hegemonia em prol da manutenção do poder e do silenciamento de agendas sociais, tidas como problemáticas para a manutenção do status quo. É essencial repensar se é realmente este tipo de desenvolvimento que se espera para a sociedade. A esse respeito, apresentamos a segunda vertente, em que destacamos contribuições de ordem prática e sociais, ao evidenciarmos o lado obscuro do processo de privatização, que mudou por completo o modus operandi da cidade de Volta Redonda/RJ, tornando-a complemente dependente da grande corporação. A seguir melhor detalhamos cada uma dessas contribuições.

No âmbito acadêmico, podemos ressaltar o argumento de que as principais causas de redução das movimentações sociais após a privatização da CSN residem na mercadificação de agendas sociais, na cooptação do sindicato dos trabalhadores, na individualidade das pessoas e na eliminação do sentimento de pertencimento de classes, além do cenário de crise de empregabilidade. Para tanto, a CSN foi estrategicamente operada pelo governo federal para conter camadas populares e reduzir movimentações sociais, a partir de uma lógica supostamente "desenvolvimentista", que desconsiderou por completo as dimensões sociais no processo.

Outra contribuição acadêmica importante residiu no emprego da Análise Crítica do Discurso e da Opção Decolonial, como bagagens teórico-analíticas, algo bastante escasso no campo da administração, sobretudo no Brasil. As bagagens empregadas possibilitaram analisar de forma crítica e historicizada as fragilidades do processo de "desenvolvimento", revestido pela lógica da privatização e fortemente amparado por estratégias sociais investidas sobre os diversos atores de não-mercado, sobretudo aos que ofereciam maior resistência (e.g. sindicato, igreja, e movimentos sociais). Verificamos que os detentores do poder político e econômico produziram e distribuíram discursos neoliberais em larga escala, sobretudo por aproximações relacionais (PEDROSO NETO, 2012; SOUZA et al., 2016), proporcionando grande consumo e repercussão, beneficiando exclusivamente os interesses da minoria global. Os discursos foram utilizados para legitimar os interesses governamentais de cada período, sendo que o processo de privatização da siderúrgica concentrou-se principalmente na ordem discursiva de CSN "gargalo" e problema social, ressaltando a utilização de estratégias sociais de soft e hard power, com atores de não-mercado da CSN, visando a naturalização da privatização e a consequente redução das movimentações sociais. O estudo da privatização sob o olhar das relações estratégicas de não-mercado foi essencial para identificarmos as diferentes ordens do discurso empregadas para moldar o ambiente de acordo com a 
"necessidade" de cada período. Como destacado em Pedroso Neto (2012), a respeito da privatização, na CSN também houve ação não somente econômica para legitimação, mas ações sociais de poder e de desenvolvimento com o ambiente que, neste trabalho, consideramos como ambiente de não-mercado.

Sobre o segundo conjunto de contribuições deste trabalho, aqui chamadas de contribuições de ordem prática e sociais, advertimos leitores e sociedade de um modo geral para a relativa redução dos movimentos sociais pós-privatização, que pôde ser verificada mediante análise do ambiente e da cidade, mas também foi corroborada no discurso dos entrevistados. Os entrevistados apontaram como principais causas de tais reduções, o poder econômico e de empregabilidade exercido sobre o município, mediante reserva de mão-deobra, além da conjuntura nacional e internacional pós-moderna, ou seja, um conjunto de graves consequências do processo de "desenvolvimento" que desconsiderou por completo as agendas e impactos sociais.

A instalação da CSN em Volta Redonda/RJ almejava a modernidade e a dependência em relação à indústria, e essa modernização agravou-se ainda mais com o "dever" de privatizar a CSN rapidamente, que propiciou desemprego, redução do poder dos sindicatos e dos próprios trabalhadores que, a partir daquele momento, deveriam agir de acordo com os novos padrões, provocando redução dos movimentos sociais de resistência e do poder das pessoas, não somente em Volta Redonda, mas em toda a região.

Ressaltamos ainda, como contribuição de ordem prática do trabalho, a urgente e atual necessidade de repensar políticas públicas, com vista ao cumprimento de agendas impostas por países centrais, como as neoliberais e de globalização, mantendo-se os ditames ocidentais, gerando grandes assimetrias sociais. Adicionalmente sobressai a necessidade de repensar o Estado mínimo, especialmente para democracias pouco amadurecidas, como o caso do Brasil. Vale destacar a relevância do trabalho num sensível contexto que revive a retomada do neoliberalismo e, por conseguinte, das privatizações, revestidas do mesmo conjunto de estratégias sociais discursivas, que empregam "desenvolvimento" como um dos principais elementos. Dessa forma, as sociedades de um modo geral e, mais especificamente a sociedade de Volta Redonda, vêm promovendo amplos benefícios a uma minoria global às duras custas de uma grande maioria, que é sistematicamente invisibilizada e subalternizada pelos ideais hegemônicos, de forma estratégica e naturalizada.

Mesmo em um contexto com forte viez liberal, a mão do Estado continua a agir, mas agora em favor de políticos e elites, tal qual vislumbrou o geográfo Milton Santos, reforçando 
a ideia de que os fenômenos "desenvolvimentistas" aparentam repetir-se ciclicamente (SANTOS, 2000). A hegemonia suportada pela mão do Estado vem tentando inclusive mercantilizar direitos sociais como a educação (ROBERTSON, 2012), água e saneamento básico (BRITO; REZENDE, 2017; COSTA, 2018), além de outros. Destacamos, inclusive, que o campo do conhecimento não deve negligenciar atores de não-mercado, pois conforme demonstrado na pesquisa, as empresas os operacionalizam estrategicamente e silenciosamente. Diferentemente do que foi prometido aos operários da CSN, o processo de privatização trouxe desemprego, devastação ambiental, gentrificação, pobreza e aumento das assimetrias sociais. Ademais, a CSN perpassou pelas três fases do capitalismo brasileiro, da transformação de país agrário a industrial e posteriormente em neoliberal, ditada pelos interesses governamentais, do mercado e das elites brasileiras. O poder da grande indústria venceu, ainda que momentaneamente, as movimentações sociais.

A partir da atual conjuntura nacional, verifica-se que privatizar não é a única alternativa, é possível conciliar eficiência e direito social, o que pode ser comprovado em casos internacionais (BRITO; REZENDE, 2017). Entretanto, além disso é importante destacar que ainda que haja eficiência nas privatizações, há de se considerar a efetividade de tal ação, ou seja se a privatização trará valor para a sociedade como um todo, diferentemente do padrão de privatização brasileiro e de tantos outros países, que levaram em consideração somente fatores econômicos e financeiros, negligenciando por completo a vertente social do “desenvolvimento". Assim, o que vemos hoje são empresas que foram privatizadas angariando lucratividade a qualquer preço - em detrimento do meio ambiente, das relações trabalhistas e sociais - ocasionando grandes tragédias ambientais e sociais, a exemplo dos crimes corporativos recém cometidos pela Vale S.A, empresa privatizada em 1997, responsável pelo rompimento de duas barragens de minério de ferro - de Mariana/MG em 2015 e de Brumadinho/MG em 2019 - provocando mortes de pessoas e animais, destruindo flora e fauna, com reflexos incalculáveis para a sociedade, para o meio ambiente e para a economia de toda região. Ademais, fatos como estes devem ser analisados sob o olhar da sua relação estratégica com os organismos de poder da sociedade.

A modernidade e o desenvolvimento prometidos, que conduziram a privatização de diversas indústrias de variados setores da economia, nos permite questionar: Desenvolvimento? Para quem? Os problemas produzidos pela privatização corroboram a ideia de que decisões governamentais e empresariais em prol do suposto "desenvolvimento" não podem negligenciar as vertentes sociais e ambientais em benefício do mercado. Como proposição 
para trabalhos futuros, sugerimos o estudo historicizado e crítico de outros processos latinoamericanos de privatização e sua relação com o ambiente em que convivem, assim como os impactos que esses processos deixaram para a empresa e para a sociedade.

\section{REFERÊNCIAS}

ABDALLA, M. M.; ALTAF, J. G. Análise Crítica do Discurso em Administração/Gestão: sistematização de um framework metodológico. Revista ADM. MADE, v. 22, n. 2, p. 35-47, 2018.

ABDALLA, M. M. Repensando o duplo movimento polanyiano a partir do desenvolvimento de estratégias sociais: um olhar sobre o setor de energia nucleoelétrica à luz da opção decolonial. 306f. Tese (Doutorado). Fundação Getúlio Vargas, Rio de Janeiro, RJ, Brasil, 2014.

ABDALLA, M. M.; FARIA, A.. Desenvolvimento local versus projeto de globalização neoliberal: refletindo sobre cidades orientadas ao mercado. Revista de Administração Pública, v. 53, n. 1, p. 84-100, 2019.

ABDALLA, M. M.; FARIA, A.; Em defesa da opção decolonial em administração/gestão. Cad. EBAPE.BR, Rio de Janeiro , v. 15, n. 4, p. 914-929, Dec. 2017. DOI: 10.1590/1679395155249.

ABDALLA, M. M.; FARIA, A. Desenvolvimento local versus projeto de globalização neoliberal: refletindo sobre cidades orientadas ao mercado. Rev. Adm. Pública, Rio de Janeiro , v. 53, n. 1, p. 84-100, 2019. DOI: 10.1590/0034-761220170088.

ALVES, M. P. Lazer operário e alienação (Volta Redonda - 1951 a 1956). 143f. Dissertação (Mestrado em História). Universidade Severino Sombra, Vassouras, RJ, 2001.

ANDERSSON, R.; TURNER, L. M. Segregation, gentrification, and residualisation: from public housing to market-driven housing allocation in inner city Stockholm. International Journal of Housing Policy, v.14, n.1, pp.3-29, 2014. DOI: 10.1080/14616718.2013.872949.

ASSIS, R.O.; LUSTOZA, R.E. Las relaciones trabajo-sociedad: un "nuevo hombre" y una "nueva" sociedad para Volta Redonda. In:International Conference Virtual City and Territory (9è: 2013: Roma). Università degli Studi Roma Tre, 2014

BACH, D.; ALLEN, D. What every CEO Needs to Know about Nonmarket Strategy. MIT Sloan Management Review, v. 51, n. 3, p. 40-48, 2010.

BALleStRIN, L. Colonialidade e Democracia. Revista Estudos Políticos, v.5, n.1, p. 191209, 2014.

BARLEY, S.R. Building an institutional field to corral a government: A case to set an agenda for organization studies. Organization Studies, v. 31, n. 6, p. 777-805, 2010.

(c) (1) $\Theta$ REAd | Porto Alegre - Vol. 26 - N. ${ }^{\circ} 1$ - Janeiro / Abril 2020 - p. 49-80. 
BARON, D.P. Business and its environment. New Jersey: Prentice Hall, 2010.

BARON, D.P. Integrated strategy: Market and nonmarket components. California management review, v. 37, n. 2, p. 47-65, 1995.

BARON, D.P.; DIERMEIER, D. Strategic activism and nonmarket strategy. Journal of Economics \& Management Strategy, v. 16, n. 3, p. 599-634, 2007.

BENTES, J.C.G; COSTA, M.L.P. A cidade-empresa e a empresa na cidade: Volta Redonda e a Companhia Siderúrgica Nacional. Anais: Seminário de História da Cidade e do Urbanismo, v. 10, n. 1, p. 1-14, 2012.

BIONDI, A. O Brasil privatizado. 1. ed. São Paulo: Geração Editorial, 2014.

BRITTO, A. L.; REZENDE, S. C. A política pública para os serviços urbanos de abastecimento de água e esgotamento sanitário no Brasil: financeirização, mercantilização e perspectivas de resistência. Cadernos Metrópole, v. 19, n. 39, 2017.

CAREGNATO, R.C.A.; MUTTI, R. Pesquisa qualitativa: análise de discurso versus análise de conteúdo. Texto Contexto Enferm, v. 15, n. 4, p. 679-84, 2006.

CARRION, R.K..; VIZENTINI, P.G.F. Globalização, Neoliberalismo, privatizações: quem decide este jogo?. 2. ed. Porto Alegre: Editora da Universidade, Universidade Federal do Rio Grande do Sul, 1997.311p.

CASANOVA, P. G. O Imperialismo, hoje. Tempo, v. 9, n. 18, p. 65-75, 2005.

CEPÊDA, V. A. Entre a economia e a política os conceitos de periferia e desenvolvimento em Celso Furtado. Sinais sociais, p. 88-119, 2012.

CEPÊDA, V. A. O pensamento político de Celso Furtado: desenvolvimento e democracia. In: el@ tina. 2004.p. 11.

CHOULIARAKI, Lilie; FAIRCLOUGH, Norman. Discourse in Late Modernity: Rethinking Critical Discourse Analysis (Critical Discourse Analysis EUP). 1999.

COSTA, A. S. M. O Mau Cheiro vem do Esgoto? Uma Análise do Caso da Desestatização da CEDAE pela Visão da Atividade Política Corporativa. Dissertação de Mestrado. Mestrado Profissional em Administração - Universidade Federal Fluminense, 2018.

COWLING, K.; TOMLINSON, P. R. Globalisation and corporate power. Contributions to Political Economy, v. 24, n. 1, p. 33-54, 2005.

DA SILVA, A.; ABDALLA, M.M. The hidden face of modernity: The case of Companhia Siderurgica Nacional in Brazil. Anais do 6 th Latinamerican And European Meeting On Organization Studies, 2016.

DA SILVA, A.; ABDALLA, M.M.; MORAES, J. Estratégia de Institucionalização: o caso da privatização da Companhia Siderúrgica Nacional (CSN). Anais do Congresso de Administração, Sociedade e Inovação, 2015.

(c) (1) $\left(\right.$ REAd | Porto Alegre - Vol. 26 - N. ${ }^{\circ} 1$ - Janeiro / Abril 2020 - p. 49-80. 
DOH, J.; MCGUIRE, S.; OZAKI, T. The Journal of World Business Special Issue: Global governance and international nonmarket strategies: Introduction to the special issue. Journal of World Business, v. 50, n. 2, p. 256-261, 2015.

DUSSEL, E. Europa, modernidad y eurocentrismo In: LANDER, E. (Ed.). La colonialidad del saber: eurocentrismo y ciencias sociales - perspectivas latinoamericanas. Buenos Aires: Clacso, 2000. p. 41-53.

FAIRCLOUGH, N. L. Critical and descriptive goals in discourse analysis. Journal of pragmatics, v. 9, n. 6, p. 739-763, 1985.

FAIRCLOUGH, N. Discurso e mudança social. Tradução de Izabel Magalhães. Brasília: Editora Universidade de Brasília, 2001.

FAIRCLOUGH, Norman. Critical discourse analysis in transdisciplinary research. A new agenda in (critical) discourse analysis, p. 53-70, 2005.

FARIA, A.; ABDALLA, M. M. O que é (estratégia de) não mercado?. Organizações \& Sociedade, v. 21, n. 69, p. 315-333, 2014a.

FARIA, A.; ABDALLA, M. M. Engajando com o Lado Mais Sombrio do Mercado e da Gestão. In: XXXVIII Encontro da ANPAD - EnANPAD, 38. Anais ... Rio de Janeiro: ANPAD, 2014b.

FLEMING, P.; SPICER, A. Power in Management and Organization Science. The Academy of Management Annals, v.8, n.1, pp.237-298, 2014.

DOI:10.1080/19416520.2014.875671.

FORTE, V.L. Colonialismo como estrutura de longa duração constituinte do capitalismo: Uma reflexão a partir de Caio Prado Júnior e Pablo González Casanova. Revista de Estudos AntiUtilitaristas e PosColoniais, v. 3, n. 2, p. 216-229, 2014.

FURTADO, C. Desenvolvimento e subdesenvolvimento. Rio de Janeiro, RJ: Fundo de Cultura, 1961.

GANDRA, M. A. R. "Cidade Vermelha” do Aço: greves, controle operário e poder popular em Volta Redonda. 136f. Dissertação (Mestrado em História) - Instituto de Ciências Humanas e Filosofia. Universidade Federal Fluminense, Niterói, RJ, Brasil, 2009.

GIL, A.C. Como elaborar projetos de pesquisa. São Paulo, v. 5, 2002.

GRACIOLLI, E.J. A privatização da CSN - da luta de classes à parceria. 1. ed. São Paulo: Expressão Popular, 2007.

GRAEBNER, M. E.; MARTIN, J. A.; ROUNDY, P. T. Qualitative data: Cooking without a recipe. Strategic Organization, v. 10, n. 3, p. 276-284, 2012.

HAESBAERT, R.; PORTO-GONÇALVES, C. W. A nova des-ordem mundial. $2^{\text {a }}$ reimpressão. Coleção Paradidáticos - Série Poder. São Paulo: Editora UNESP, 2006. 
HE, Y. How firms integrate nonmarket strategy with market strategy: evidence from mainland of China. Journal of American Academy of Business, v. 10, n. 1, p. 357-361, 2006.

IBARRA-COLADO, E. Neoliberal globe/centrism and international management blindness: the indispensable decolonial turn. GUEDES, A.; FARIA, A. International management and international relations: a critical perspectives from Latin America. New York: Routledge, p. 29-60, 2010.

IBARRA, D. O neoliberalismo na América Latina. Revista de Economia Política, v. 31, n. 2, p. 238-248, 2011.

LAMY, M. Metodologia da pesquisa jurídica: técnicas de investigação, argumentação e redação /Marcelo Lamy. - Rio de Janeiro: Elsevier, 2011.

LANDER, E. et al. (Ed.). A colonialidade do saber: eurocentrismo e ciências sociais: perspectivas latino-americanas. CLACSO, Consejo Latinoamericano de Ciencias Sociales= Conselho Latino-americano de Ciências Sociais, 2005.

LIMA, R.J.C. CSN e Volta Redonda: uma relação histórica de dependência e controle. Política \& Sociedade, v. 12, n. 25, p. 41-64, 2014.

MIGNOLO, W. D. A colonialidade de cabo a rabo: o hemisfério ocidental no horizonte conceitual da modernidade. In: LANDER, E. (Org.). A colonialidade do saber: eurocentrismo e ciências sociais - perspectivas latino-americanas. Buenos Aires: CLACSO, 2005. p. 71-103. (Colección Sur Sur).

MINAYO, M.C.S (organizadora); DELSANDES, S.F; GOMES, R. Pesquisa Social -Teoria, Método e Criatividade. Petrópolis: Editora Vozes, 2009.

MOREIRA, A.D.S. Contribuições da Teologia da Libertação para os Movimentos Sociais. Caminhos, v. 10, n. 2, p. 37-55, 2012.

MOREL, R.L.M. A construção da "família siderúrgica"- Gestão paternalista e empresa estatal. In: RAMALHO, J. R. (org.); SANTANA, M. A. Trabalho e tradição sindical no Rio de Janeiro: a trajetória dos metalúrgicos. Rio de Janeiro: DP\&A, 2001.

MOREL, R.L.M. A ferro e fogo: construção e crise da" família siderúrgica": o caso de Volta Redonda (1941-1968). Tese (Doutorado em Sociologia). Faculdade de Filosofia, Ciências e Letras Humanas, Universidade de São Paulo, São Paulo, 1989.

NORONHA, E.G. Ciclo de greves, transição política e estabilização: Brasil, 1978-2007. Lua Nova, v. 76, p. 119-168, 2009.

NYE, J. S. Soft Power: The Means to Success in World Politics. New York: Public Affairs, 2005.

PALMEIRA, A.F. A Nova Face da "Cidade do Aço": crise do capital, trabalho e hegemonia em Volta Redonda (1992-2008). Dissertação. Programa de Pós Graduação da Universidade Federal Fluminense. Niterói: UFF-RJ, 2012. 
PEDROSO NETO, A. J. A PRIVATIZAÇÃO DE UMA EMPRESA: uma ação econômica enraizada nas relações sociais. Caderno CRH, v. 25, n. 66, 2012.

PEREIRA, M. F. V. O território sob o efeito modernizador: a face perversa do desenvolvimento. Interações (Campo Grande), p. 63-69, 2006.

PEREIRA, S. Sindicalismo e privatização: o caso da Companhia Siderúrgica Nacional. Tese de Doutorado. Tese (Doutorado em Ciências-Sociologia). PPGSA/IFCS/UFRJ, 2007.

PEREIRA, S.M. CUT e Força Sindical em Volta Redonda: modelos de sindicalismo ou trajetórias de lideranças?. Enfoques, v. 5, n. 2, p. 103-119, 2006.

PINTO, C.R.J. Globalização vis-a-vis a história do nacionalismo na América Latina: o casodo Brasil. Pensamento Plural, n. 11, p. 7-25, 2014.

PORTO-GONÇALVES, C.W.; QUENTAL, P.D.A. La colonialidad del poder y los desafíos de la integración regional en América Latina. Polis (Santiago), v. 11, n. 31, p. 295-332, 2012.

QUIJANO, A. Colonialidade do poder, eurocentrismo e América Latina. In: LANDER, E. A colonialidade do saber: eurocentrismo e ciências sociais. Perspectivas latino-americanas. Buenos Aires: CLACSO, p. 107 - 131, 2005.

ROCHA, D.; DEUSDARÁ, B.. Análise de Conteúdo e Análise do Discurso: aproximações e afastamentos na (re) construção de uma trajetória. Alea: Estudos Neolatinos, v. 7, n. 2, p. 305-322, 2005.

ROBERTSON, S. L. A estranha não morte da privatização neoliberal na Estratégia 2020 para a educação do Banco Mundial. Revista Brasileira de Educação, v. 17, n. 50, 2012.

SANTOS, M. Por uma outra globalização: do pensamento único à consciência universal.Rio de Janeiro: Record, 2000.

SAWAYA, R. Poder econômico, desenvolvimento e neoliberalismo no Brasil. Revista da Sociedade Brasileira de Economia Política, n. 39, p. 124-149, 2014.

SILVA, E.L.D; MENEZES, E.M. Metodologia da pesquisa e elaboração de dissertação. 3. ed. rev. atual. - Florianópolis: Laboratório de Ensino a Distância da UFSC, 2005.

SILVA, E. R. D.; GONÇALVES, C. A. Possibilidades de incorporação da análise crítica do discurso de Norman Fairclough no estudo das organizações. Cadernos EBAPE. BR, v. 15, n. 1, p. 1-20, 2017.

SUNKEL, O. Desenvolvimento, subdesenvolvimento, dependência, marginalização e desigualdades espaciais: por um enfoque totalizante. In: BIELSCHOWSKY, R. (org.). Cinqüienta anos de pensamento na CEPAL-Rio de Janeiro: Record/CEPAL, 2000-v. 2, p. 521-566, 2000.

THEBALDI, B. Estado de Violência Estatal: O Estado como Agente de Violência, no Contemporâneo. Razón y Palabra, v. 19, n. 89, 2015. 
VAN DIJK, T. A. Discurso y poder. Editorial Gedisa, 2011.

ZHENG, S.; KAHN, M. E. Does Government Investment in Local Public Goods Spur Gentrification? Evidence from Beijing. Real Estate Economics, v.41, n.1, pp.1-28. https://doi.org/10.1111/j.1540-6229.2012.00339.x, 2013. 